\title{
Portrait or Parable?: Pierre Mignard and the Mystery of Madame de Maintenon
}

\author{
Eelco Nagelsmit \& Lars Cyril Nørgaard
}

One of the best kept 'secrets' at the court of Louis XIV was the precise nature of the king's relationship to the woman with whom he spent the last thirty-five years of his life: Françoise d'Aubigné (1635-1719), the Marquise de Maintenon.,1 Historians agree that the unlikely couple was probably joined in marriage. This would have taken place after the period of mourning that followed the death of Queen Marie Thérèse (1638-1683). However, no evidence of this union survives. A few individuals must have been present as witnesses, but apparently they took their secret to the grave. ${ }^{2}$ Indeed, a royal mésalliance would have complicated political matters: it was thus never publicly acknowledged and thereby remained a secret. This presented the court - especially the royal family - with insurmountable problems of precedence and protocol. If asked about it, the 'secret wife' persistently dodged the question. Nevertheless, all the world seems to have been aware of Madame de Maintenon's unique status, and courtiers responded with various degrees of bemusement. This is illustrated in an epigram by playwright and poetess Catherine Bernard (1662-1712), ${ }^{3}$ who frequented the salons of her time:

* This work draws from interdisciplinary research at the Danish National Research Foundation Centre for Privacy Studies (DNRF 138), based at the University of Copenhagen and directed by Mette Birkedal Bruun. We would like to thank prof. Bruun and the organizers of the Lovis Corinth Colloquium viII Quid est Secretum, Agnès Guiderdoni, Ralph Dekoninck, and especially Walter Melion.

1 Francoise d'Aubigné became affiliated to court as governess of Louis XIV's illegitimate children with his mistress, Françoise-Athénaïs de Rochechouart, the Marquise de Montespan (1640-1707). This charge was undertaken in 1668 , and when the children were finally recognized in 1673 as the offspring of the king, their governess followed them to court. By 168 o, Madame de Maintenon had built a personal relationship with the king: with Montespan's fall from royal grace, Maintenon, increasingly, became the new favourite.

2 Though modern historians agree that the secret marriage must have taken place, even today, they disagree as to when and under what circumstances this happened. It most likely took place on the eve of 9-10 October 1683 . At her death in 1719, Maintenon reportedly burned every document that might provide evidence of the marriage.

3 Catherine Bernard (1663?-1712) is best known for her two plays Laodamie, reine d'Epire (1689) and Brutus (169o). Both tragedies were performed by the Comédiens du Roi at the Théâtre

(C) EELCO NAGELSMIT \& LARS CYRIL NØRGAARD, 2020 | DOI:10.1163/9789004432260_017

This is an open access chapter distributed under the terms of the CC. BY 4.8 license 
À Madame de Maintenon, epigramme:

On ne sait sivous êtes reine,

Incomparable Maintenon;

Mais que vous le soyez ou non,

C'est une chose fort certaine,

Qu'il est beau d'en faire douter,

D'en fuir le rang, l'honneur, et de le mériter. ${ }^{4}$

To Madame de Maintenon, epigram:

No one knows if you are queen,

Incomparable Maintenon;

But whether you are or not,

It is most certainly the case

That to cast doubt about it is beautiful,

[That] to flee the rank, the honour, and [instead] to be worthy of it

[is beautiful].

Dwelling on the mystery of Madame de Maintenon's position, Bernard presents 'queenship' as a station about which doubt must be cast: this blurring of identity derives from humility and demonstrates nobility of the soul. In this paper, we argue that Maintenon cultivated the ambiguity of her position, even while relying upon artistic intervention to manifest it and shape her public image.

In 1694, the eighty-two-year-old Peintre du Roi Pierre Mignard (1612-1695) painted two portraits of Louis XIV and his wife. An old acquaintance, ${ }^{5}$ Mignard

Français. During the 18th century, these plays were suggested to be the work of Bernard's cousin, the philosopher Bernard le Bovier de Fontenelle (or Corneille, who was related to Fontenelle's mother). Bernard's contemporaries knew and admired her especially for her poetry. She won the prize of the Académie Française in 1691, 1693 and 1697, which earned her a royal pension from Louis XIV. During her public life, she frequented the salons of the duchesse de Monthausier, the duchesse de Bouillon and Madame de Coulanges. Bernard stopped publishing in 1698 and died virtually unknown in 1712. See Barbafieri C., "Le théâtre de Catherine Bernard, ou comment être moderne dans le genre tragique à la fin du XVII ${ }^{\mathrm{e}}$ siècle", in Bahier-Porte C. - Poulouin C. (eds.), Écrire et penser en Moderne (1687-1750) (Paris: 2015) 321-336.

4 The French original and an English translation is cited in Shapiro N., French Women Poets of Nine Centuries: The Distaff and the Pen (Baltimore: 2008) 386-387. Also see Bernard Catherine, Piva F. (ed.), Oeuvres complètes, 2 vols. (Paris - Fasano: 1999) 408-409.

5 Mignard had been a friend of the poet Paul Scarron (1610-1650), who Françoise had first met in late $165^{1}$ and married on 4 April 1652. To the friendship between Scarron and Mignard, see De Boislisle A., Paul Scarron et Françoise d'Aubigné. D'après des documents nouveaux (Paris: 1894) 133-143. 
depicted Madame de Maintenon in the guise of her namesake, the fifteenthcentury saint Frances of Rome (1384-1440). In its time, this portrait was frequently copied and abundantly praised, yet it has been all but neglected by art historical inquiry. ${ }^{6}$ Our paper places Mignard's portrait squarely in the specific political and religious context of the late Ludovician court, where worldly splendour was out of fashion, and Christian virtue à la mode. We do so by combining art historical and church historical approaches and by taking account of little known sources on Maintenon's devotional practices, i.e., the letters of spiritual direction written by Paul Godet des Marais (1648-1709), her 'directeur de conscience. ${ }^{7}$ In addition to exploring the portrait's iconography, we question the conventions and culturally encoded practices of viewing portraiture in the context of Louis XIV's court. ${ }^{8}$ Building on the analogy between secret spouse and the saint - les deux Françoises - Mignard not only produced a historiated portrait, but also a 'visual parable'. He designed a portrait that could perform multiple functions on different interpretative levels and for various audiences. In other words, the portrait dissimulates. The parabolic level has hitherto gone unnoticed, because fully understanding it requires a religiously informed mode of viewing. Thus, the painter masterfully played with the secrecy and mystery that surrounded Maintenon's impossible position as 'Queen without a Crown'.

6 In her monograph on the painter, Lada Nikolenko limits herself to listing early sources: Nikolenko L., Pierre Mignard: Portrait Painter of the Grand Siècle (Munich: 1983) 95-96. Thierry Bajou mentions the various extant versions: Bajou T., "À propos de quelques tableaux de Mignard à Versailles", in Boyer J.-C. (ed.), Pierre Mignard “le Romain” (Paris: 1997) 195-224 $\left(203^{-205}\right)$. In his collection catalogue, Bajou connects the gilded letters with a miracle from the saint's vita, but fails to elaborate this connection: Bajou T., Les Peintures à Versailles: XVII Siècle (Paris: 1998) 266-267. Fumaroli briefly touches upon Mignard's portrait in his study of Poussin's rediscovered altarpiece in the Louvre: Fumaroli M., De Rome à Paris: peinture et pouvoirs aux XVII ${ }^{e}$ et XVIII ${ }^{e}$ siècles (Dijon: 2007) 106-163 (116-117).

7 To Godet des Marais' role as spiritual director, see Nørgaard L.C., Sources of Spiritual direction (Ph.D. dissertation, University of Copenhagen: 2017).

8 See Coquery E. (ed.), Visages du Grand Siècle: Le portrait français sous le règne de Louis XIV, 1660-1715, exh. cat. Musée des Beaux-Arts, Nantes - Musée des Augustins, Toulouse (Paris: 1997), especially Brême D., "Portrait historié et morale du Grand Siècle" 91-104. On historiated portraits, see also Schneider M., Bildnis - Maske - Galanterie: das "portrait historie" zwischen Grand Siècle und Zeitalter der Aufklärung (Berlin - Munich, 2019). 
The three-quarter length portrait depicts the richly dressed sitter in a red velvet armless chair at a table with an hourglass, a commonplace attribute denoting consciousness of the brevity of life and the vanity of worldly matters [Fig. 15.1]. ${ }^{9}$ Her hair is largely covered with a transparent silk veil, a sign of humility. Fondling the fur trim of her cloak, she gently strikes her breast with the right hand, a gesture of contrite humility. ${ }^{10}$ At the same time, the erminetrimmed dark blue velvet mantle seems to suggest royal status. One attribute stands out in the composition: in her lap, the sitter conspicuously holds a book of hours, showing a text in partly gilded letters [Fig. 15.2].11 These are clearly legible, and read: 'Ant. In odorem unguentorum tuorum currimus: adolescentulae dilexerunt te nimis' (Ant.: into the odor of thy ointments we run: young maidens have loved thee exceedingly). This antiphon, drawn from the Canticle of Canticles, has a variety of connotations to which we shall turn below.

Pierre Mignard's first biographer Simon-Philippe Mazière de Monville $(\dagger 1777)$, who claims to have based his biography on the notes of Mignard's daughter, Catherine-Marguerite Mignard (1652-1742), suggests that the portrait of Madame de Maintenon formed part of a pair. The portrait of Louis XIV is now presumably lost, but known from an engraving [Fig. 15.3]. ${ }^{12}$ Monville renders

9 The portrait exists in various copies; one is in the collection of the Louvre (inv. 6657), and the Château de Versailles holds two versions, one original (inv. MV 3637 ) and a later version en pied (inv. MV4268). To the two paintings at Versailles, see Da Vinha M. - Maral A. (eds.), Madame de Maintenon. Dans les allées du pouvoir, exh. cat., Château de Versailles (Versailles: 2019) 74-75. One further copy exists in Burghley House (PIC465). To the different versions, see also Nikolenko, Pierre Mignard 95-96.

10 This gesture finds its origin in the parable of the Pharisee and the tax collector from the Gospel of Luke: 'everyone who exalts himself will be humbled, but he who humbles himself will be exalted' (Luke 18:9-14) and constitutes a liturgical act prescribed for the Confiteor as well as for the Eucharist.

11 Excerpt from Canticle 1:1-3 in Little Office of Our Lady: 'osculetur me osculo oris sui quia meliora sunt ubera tua vino fragrantia unguentis optimis. Oleum effusum nomen tuum; ideo adolescentulae dilexerunt te trahe me, post te curremus in odorem uguentorum tuorum. Introduxit me rex in cellaria sua; exsultabimus et laetabimur in te, memores uberum tuorum super vinum recti diligunt te' (Let him kiss me with the kiss of his mouth for your breast are better than wine, fragrant with the finest ointments your name is oil poured out, that is why the girls have loved you, draw me after you, in your ointments we will run, the king led me into his cellars, we will rejoice and be glad in you remembering your breasts better than wine the righteous love you). As an antiphon from the Little Office, the specific excerpt seen in Mignard's painting comes from the canonical hours of Lauds and Sext, that is, the Morning and Noon Offices.

12 De Lastic G., "Contribution à l'oeuvre de Pierre Mignard, portraitiste", Bulletin de la Société de l'Histoire de l'Art français (1980) 167-176 (173). 


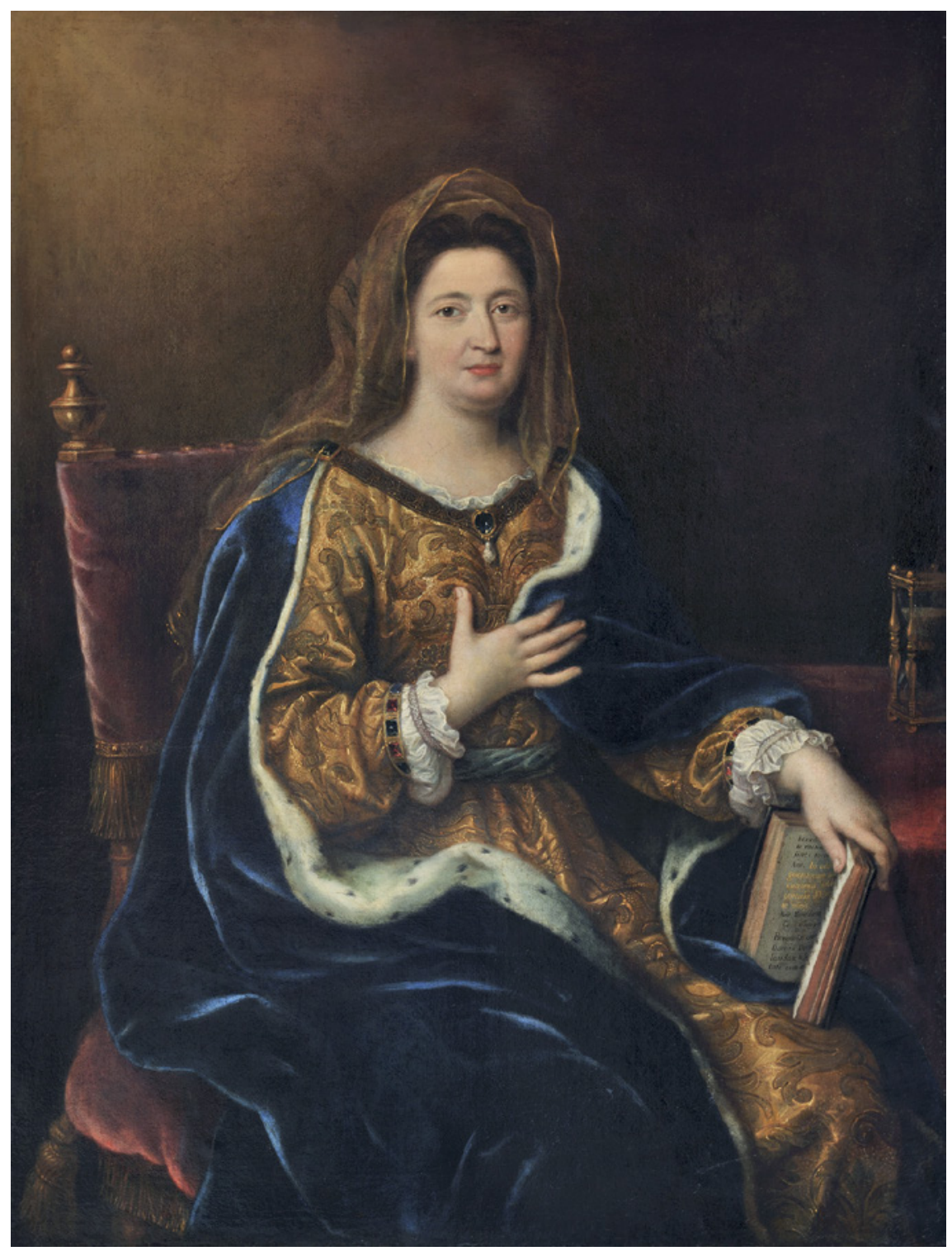

FIG R 15.1 Pierre Mignard, Francoise d'Aubigné, Marquise de Maintenon as Saint Frances of Rome (1694). Oil on canvas, $128 \times 97 \mathrm{~cm}$. Versailles, Châteaux de Versailles et de Trianon

PHOTO C RMN-GRAND PALAIS / JEAN-MARC MANAÏ 


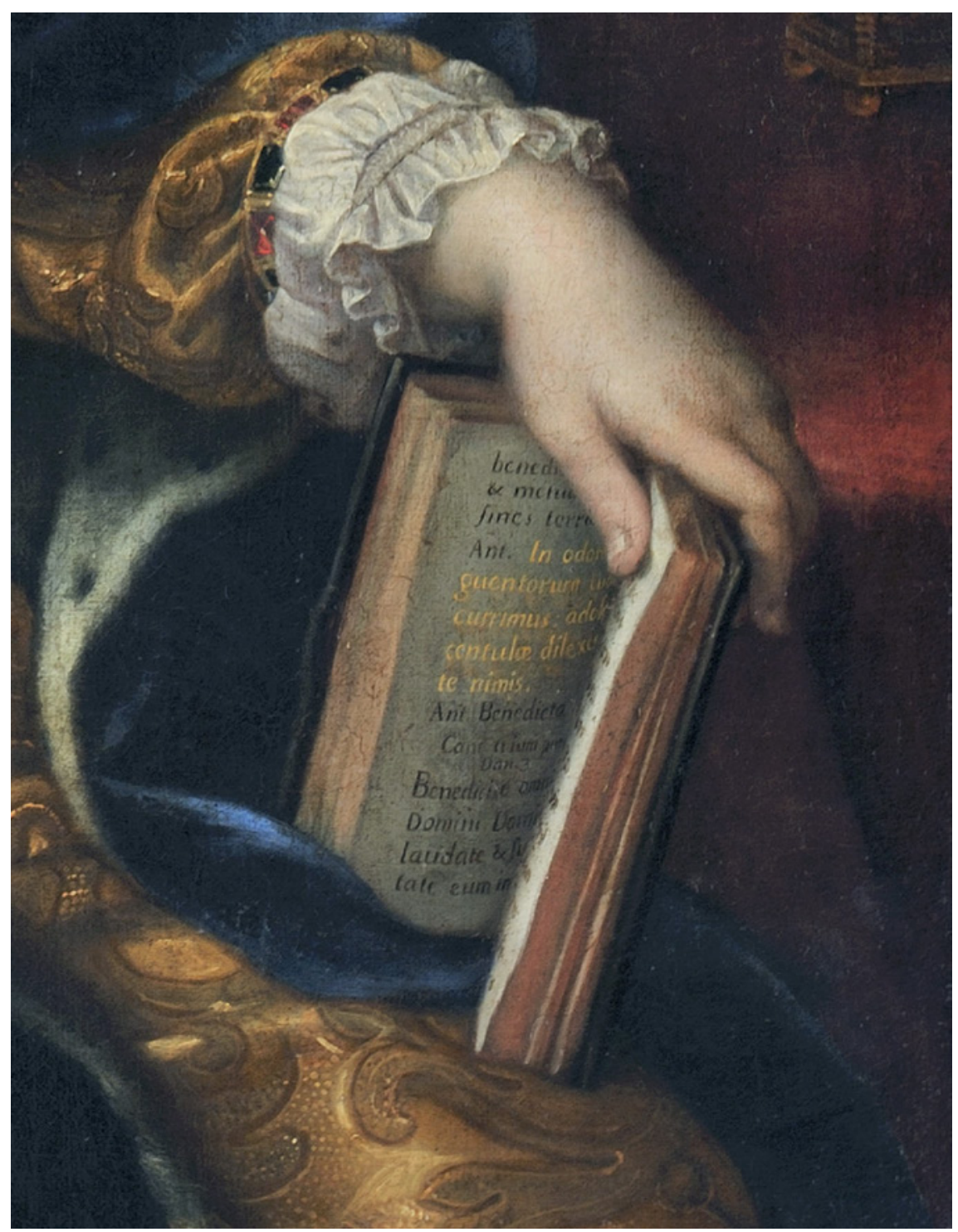

FI GURE 15.2 Pierre Mignard, Francoise d'Aubigné, Marquise de Maintenon as Saint Frances of Rome (1694). Oil on canvas, $128 \times 97 \mathrm{~cm}$. Detail, Book of Hours. Châteaux de Versailles et de Trianon

PHOTO (C) RMN-GRAND PALAIS / JEAN-MARC MANAÏ 


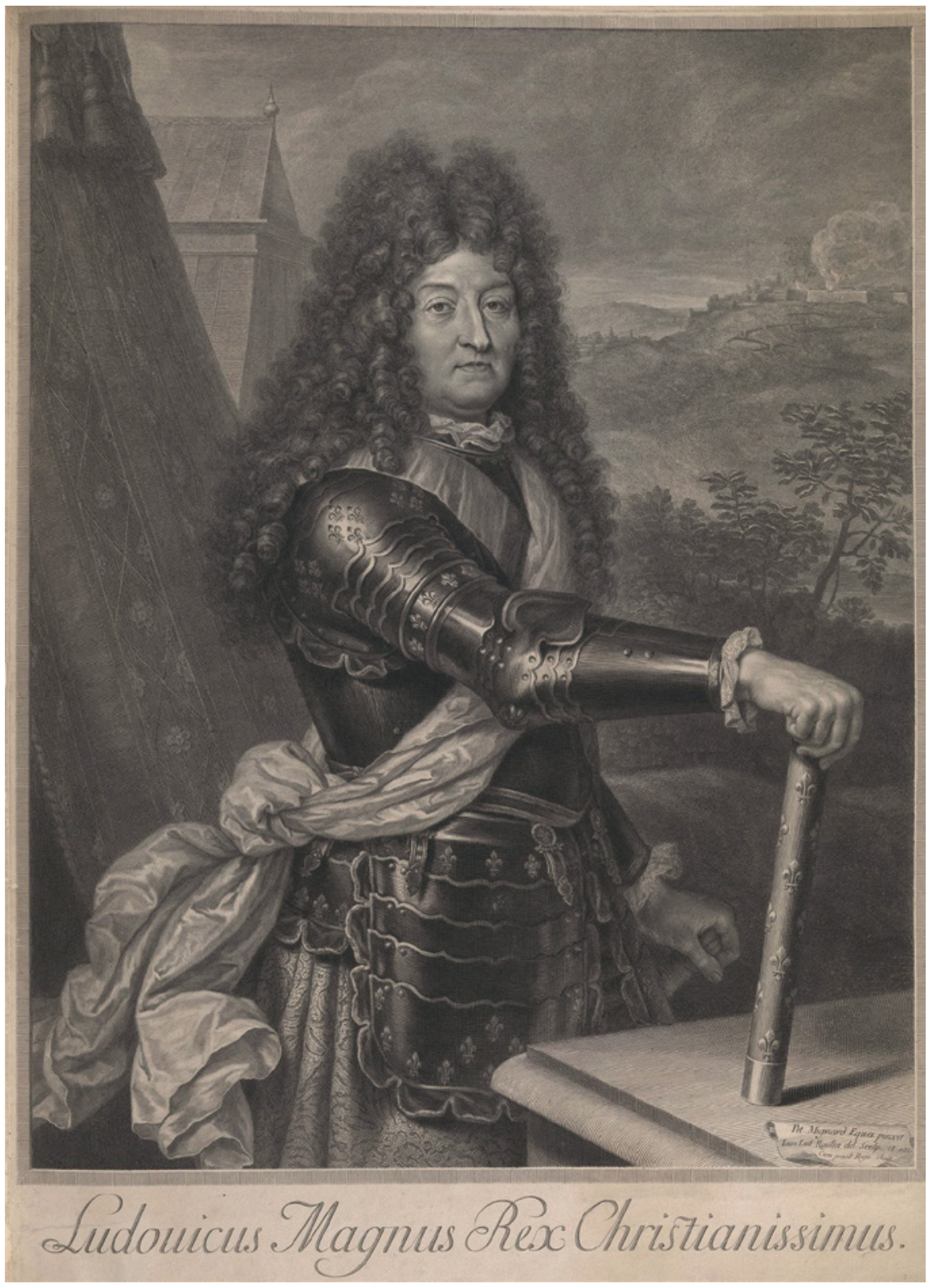

FIGURE 15.3 Jean-Louis Roullet (engraver) after a lost painting by Pierre Mignard, Louis XIV as commander in chief (c. 1694). Engraving, 66,o $\times 52,5 \mathrm{~cm}$ ROYAL COLLECTION TRUST / (C) HER MAJESTY QUEEN ELIZABETH II 2020 
a rather detailed account of how these two portraits came into being, and especially praises the portrait of Madame de Maintenon as 'sublime' and as one of Mignard's best works. ${ }^{13}$

Ce portrait où le Peintre a représenté Madame de Maintenon en Sainte Françoise, Dame Romaine dont elle portoit le nom, est d'un genre sublime. L'esprit et l'âme de celle qui en est l'objet s'y reconnoissent. L'auteur qui l'avoit vûë dans sa jeunesse, en avoit sçû rappeller les agrémens, sans alterer le caractere de l'âge qu'elle avoit alors. Il a tiré de l'habillement tout ce qui pouvoit être avantageux à sa peinture \& à son sujet. C'est un des plus beaux morceaux qui soient sortis de sa main, \& qui fasse plus d'honneur à son esprit. ${ }^{14}$

This portrait where the painter has represented Madame de Maintenon as saint Frances, Roman lady of which she bears the name, is of sublime style. The spirit and the soul of the sitter are recognised [in it]. The author who had known her in her youth, knew how to recall the charms, without altering the character of the age she had then. He drew from the garments all that could be advantageous to his painting and to his subject: it is one of the most beautiful pieces by his hand, and which does most honour to his wit.

It may not be immediately apparent to a modern-day viewer why this portrait of a middle-aged woman, dressed up as a pious and demure matron saint, was considered sublime or keen-witted. What does Monville mean when he suggests that the greatness of spirit and the soul of the sitter, as well as the wit of the painter, may be recognized in this portrait? Sources on the portrait's contemporary reception eulogize the artist as well, precisely for striking the right

13 According to Monville, Maintenon was initially disinclined to having her portrait made, but eventually succumbed to external pressure, Mazière de Monville Simon-Philippe, La Vie de Pierre Mignard, premier peintre du roy, par l'abbé de Monville, avec le poème de Molière sur les peintures du Val-de-Grâce et deux dialogues de M. de Fénelon, Archevêque de Cambray, sur la peinture (Paris, Jean Boudot - Jacques Guérin: 1730) 173. It should be noted that portraits of her and the king as founders of the religious community at Saint-Cyr had already been made for its 'salle de communauté' in 1688-1689 by Nicolas René Jollain the Elder and Louis Ferdinand Elle the Elder, an ensemble which was complemented in 1690 by Mignard's chimneypiece Christ between soldiers; to this ensemble, see Bruun M.B Havsteen S.R. - Mejrup K. - Nagelsmit E. - Nørgaard L.C., "Withdrawal and Engagement in the Long Seventeenth Century: Four Case Studies", Journal of Early Modern Christianity 1 (2015) 249-343 (277-297).

Monville, La Vie de Pierre Mignard 173-174. 
chord in the way he represented the sitter. For instance, we read in a letter from Madame de Coulanges (1641-1713) to Madame de Sévigné (1626-1696):

Au reste, madame, j'ai vu la plus belle chose qu'on puisse jamais imaginer ; c'est un portrait de madame de Maintenon, fait par Mignard: elle est habillée en Sainte Françoise Romaine. Mignard l'a embellie ; mais, c'est sans fadeur, sans incarnat, sans blanc, sans l'air de la jeunesse ; et sans toutes ces perfections, il nous fait voir un visage et une physionomie au-dessus de tout ce que l'on peut dire; des yeux animés, une grâce parfaite, point d'atours ; et avec tout cela aucun portrait ne tient devant celui-là. ${ }^{15}$

Furthermore, Madame, I have seen the most beautiful thing that one could ever have imagined: a portrait of Madame de Maintenon by Mignard. She is dressed as saint Frances of Rome, and Mignard has made her beautiful but without insipidity, without rouge, without powder, without the air of youth. In the absence of all these perfections, he instead presents us with a face and a physiognomy beyond what words can express: eyes animated, a perfect elegance, and no additional attire. With all this, no other portrait lives up to this one.

Madame de Coulanges also sent Sevigné a madrigal, which the aforementioned Catherine Bernard allegedly composed impromptu upon seeing the portraits of Maintenon and the king.

À Mignard, sur les portraits de Louis XIV et de Madame de Maintenon.

Oui, votre Art, je l'avoüe, est au-dessus du mien

J'ai loué mille fois notre invincible Maître,

Mais vous, en deux portraits, vous le faites connoître:

L'on voit aisément dans le sien

Sa bonté, son cour magnanime :

Dans l'autre on voit son goût à placer son estime.

Ah! Mignard que vous louez bien! ${ }^{16}$

15 Letter from Madame de Coulanges to Madame de Sévigné, 29 October 1694: Sévigné Marie de Rabutin-Chantal, Lettres de Madame de Sévigné, de sa famille et ses amis, ed. Monmerqué L.-J.-N., 14 vols. (Paris: 1862-1868) vol. 10 (1862), 207-209 (208).

16 Sévigné, Lettres 209. Also cited in Monville, La Vie de Pierre Mignard 174. For a discussion, see Bernard Catherine, Piva F. (ed.), Oeuvres 404-405. 
To Mignard, on the portraits of Louis XIV and Madame de Maintenon. Yes, your Art, I confess, is above mine

I have praised a thousand times our invincible Master [the king],

But you, in two portraits, you make him known:

It is easy to see in his own [portrait]

His worth, his noble heart:

In the other [portrait of Maintenon], one sees his taste in the placing of his esteem.

Ah! Mignard how well you praise!

This time Bernard takes as her point of departure the contest or paragone between painting and poetry, a recurrent topic of salon conversation, praising the artist's capacity to praise. She closely relates the portrayal of Madame de Maintenon as saint Frances to the royal portrait, which makes it a token of the king's good judgement.

Yet, the identity of the depicted double-subject - somewhere between 'saintliness' and 'queenship' - remains elusive. Robes of state she could never wear, but the laws of decorum did not forbid an ermine-trimmed mantle, playing with the ambiguity of the sitter's supposed marital status and her saintliness. ${ }^{17}$ It is to the specific nature of this equivocal position that we shall now turn.

\section{Controversy}

At Madame de Maintenon's instigation, the king founded, in 1686, an educational institution of unprecedented nature and scale. La Maison Royale de Saint Louis at Saint-Cyr near Versailles targeted girls from impoverished noble families, and it would become Maintenon's life work as 'foundatrice' and 'institutrice' [Fig. 15.4]. In more general terms, the institution served the political purpose of reproducing social customs and transmitting them to future generations of wives and mothers in households of the lesser nobility. The king's wife closely supervised their education, which put great emphasis on cultural activities and systematically divested the girls of worldly preoccupations.

The school at Saint-Cyr and its community of teachers, Les Dames de Saint Louis, initially did not adhere to any established monastic rule, but professed revocable vows of obedience, chastity, poverty and education. In January 169o,

17 Collections of partly or completely fictitious anecdotes de cour published in the nineteenth century dwell on this ambiguity, e.g. Dubois Guillaume, Mémoires du cardinal Dubois, ed. Lacroix P., 4 vols. (Paris: 1829), vol. 2, 113-114. 


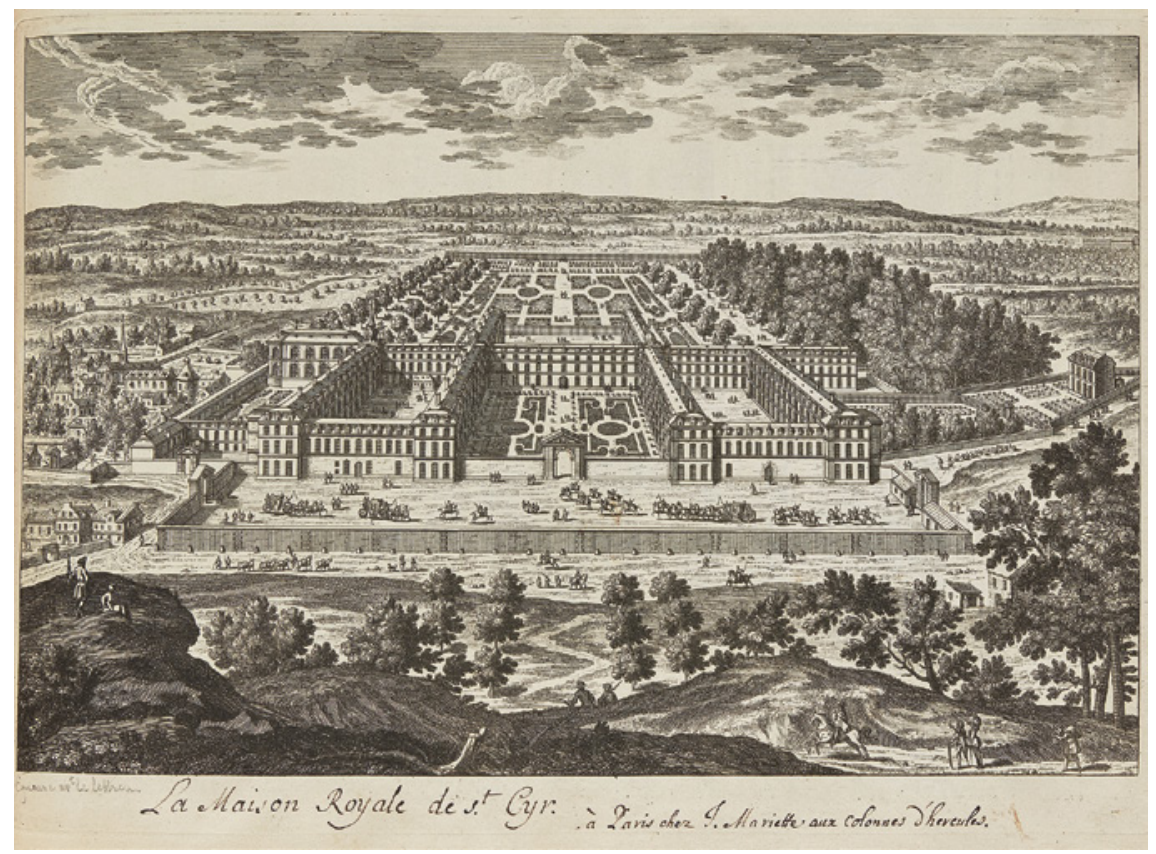

FIGURE 15.4 Adam or Nicolas Perelle (engraver and designer), perspective view of La maison Royale de Saint-Cyr (c. 169o). Engraving, 24,5×35,5 cm. Plate 154 from Jean Mariette, Veuës des plus beaux endroits de Versailles, Recueil de gravures de la collection de Grossœuvre 140, Versailles, Châteaux de Versailles et de Trianon

PHOTO (C) RMN-GRAND PALAIS / CHRISTOPHE FOUIN

internal tensions and exterior pressure from the Holy See set a process in motion which culminated in December 1692, when the Ladies of Saint Louis officially adopted the Rule of saint Augustine. One year later, on 11 December 1693, the first solemn vows were professed, and in January 1694 the first superior was appointed. Although the Ladies were admonished to take religious vows, they could not be coerced to do so, since such a decision, legally and theologically, required free will. We should thus observe that Madame de Maintenon, when Mignard portrayed her in the guise of saint Frances, had just recently become the 'foundatrice' of a monastery and 'institutrice' of its religious community.

Before the process of regulation, the controversial Madame Guyon $(1648-1717)$ had frequented the community at Saint-Cyr. ${ }^{18}$ In various ways and

18 On the grounds of her teachings, Madame Guyon was imprisoned at la Visitation de la Rue Saint-Antoine in Paris from late January until early September 1688. On her release, she joined with the group of filles de Sainte Geneviève housed at the Hôtel de Miramion, 
for various reasons, she was suspected of entertaining unorthodox views on prayer as the road to complete self-abnegation and a wholly disinterested love of the divine. Already in 1689, Guyon's publications had come under suspicion of entertaining heterodox ideas redolent of the so-called 'Quietists'. During 1692 and 1693, the circulation of Guyon's texts and ideals became increasingly problematic. Initially, this was an offshoot of the regulation of the royal foundation. Tasked with overseeing the Ladies' religious praxis, male ecclesiastics recorded the influx of Guyon's writings and found their message impossible to reconcile with a regulated life. In March 1693, Mme Guyon was officially barred from entering the site at Saint-Cyr, and the subsequent Conférences d'Issy, lasting from July 1694 until March 1695, established her position as heretical. ${ }^{19}$ At Versailles, fears of 'Quietism' exploded as François Fenelon (1651-1715), Archbishop of Cambrai, refrained from cutting ties with Madame Guyon. Since August 1689, Fénelon had been preceptor to the Dauphin's oldest son, the Duke of Burgundy. For theological reasons, he maintained, initially, that Madame Guyon's position could not straightforwardly be equated with heresy, because it corresponded to a specific part of Christian tradition. Facing down Jacques-Bénigne Bossuet (1627-1704), Louis-Antoine de Noailles (16511729) and Louis Tronson (1622-1700), Fénelon refused to back down, and an article was included in the proceedings of the Conférences d'Issy, which would fan the flames of the ensuing debate between Bossuet and Fénelon.

Madame de Maintenon's role in this theological controversy is important but also difficult to determine. Clearly, she could not afford to be enmeshed in irregularities. However, Fénelon was a close ally. At Saint-Cyr, he actively participated in the process of regulation, acting as spiritual director to the Ladies of Saint Louis and coauthoring the new Constitutions and Regulations.

where her daughter was married on 26 August 1689. Madame Guyon followed the newlyweds to their living space, where she stayed 'deux ans et demi' - that is, until around February 1692, cf. Guyon Jeanne-Marie, La Vie par elle-même et autres écrits par ellemême, ed. Dominique Tronc, 2 vols, (Paris: 2014) vol. 2, 771. During this period, Guyon entered Saint-Cyr for the first time. She could here visit Françoise-Silvine Le Maistre de La Maisonfort (1663-1729), who was her cousin and, in 1688, had argued Guyon's case before Madame de Maintenon. Initially, the king's wife thus supported Madame Guyon and granted her access to Saint-Cyr.

19 Initially, the conferences at Issy were supposed to be held in secret. Especially, Maintenon had no interest in making the accusations against Guyon public. However, the Archbishop of Paris, François de Harlay de Champvallon (1625-1695), published a surprise Ordonnance in late 1694, which formulated a rather vulgar line of critique: the attempt to keep the process a secret hereby turned out to have been a pipe dream. Now, the conferences had to be finished and Bossuet together with his fellow bishop Noailles had to speak out in public, cf. Le Brun J., La spiritualité de Bossuet (Paris: 1972) 554-562. 
Furthermore, Maintenon was closely linked to a courtly network that gravitated towards both Guyon and Fénelon. From 1690 until early 1693, she participated in weekly conferences carried out in the personal lodgings of the Duchess of Chevreuse and others. ${ }^{20}$ During these sessions, she and fellow courtiers would voice personal queries and, in response, Fénelon drafted spiritual texts that, subsequently, circulated amongst members of this 'secret' society. Indeed, the king's wife seems to have disseminated written material to individuals who had not attended the spiritual conferences: letters and spiritual texts were forwarded to the community at Saint-Cyr.

During the early stages of the process against Madame Guyon, a compilation of Fénelon's spiritual texts also found its way to one of the men charged with carrying out the examinations. In June 1694, Louis Tronson, the superior of Saint-Sulpice, was thus contacted by the bishop of Chartres, Paul de Godet des Marais, who was also Maintenon's spiritual director [Fig. 15.5]. ${ }^{21} \mathrm{~A}$ former Sulpician, Godet made Tronson aware of a number of problematic expressions that Fénelon had used in letters and texts addressed to Maintenon. In total, he transmitted four volumes, referred to as the 'livres rouges', where he had highlighted certain passages. Tronson shared Godet des Marais' worries with Fénelon in the fall of $1694,{ }^{22}$ when the examination of Guyon was entering its final and crucial stages. In November 1694, Fénelon drafted a written response and thereby reaffirmed what he had already expressed in letters: he deemed the process against Madame Guyon nothing but a veiled attack against him. ${ }^{23}$ On a variety of levels, 'Quietism' thus posed a serious threat to Madame de

20 To these weekly sessions, see Ledieu François, "Mémoires de l'abbé Ledieu sur le quiétisme” [1699], ed. Levesque E., Revue Bossuet 7 (1907) 19-56 (24); Phélypeaux Jean, Relation de l'origine du progrès et de la condamnation du quiétisme répandu en France, 2 vols. (s.l, s.n: 1732) vol. 1, 43 .

21 As bishop of Chartres, Godet was vested with episcopal authority over the royal foundation at Saint-Cyr. He was the driving force behind the regulation of the site, carrying out official visits and numerous conferences with the Ladies of Saint Louis. Furthermore, Godet had also acted, since late 1689 or early 169o, as the unofficial director of Madame de Maintenon's conscience. This title became official in March 1691, and in the capacity of spiritual direction he wrote a large body of letters and small texts, which engage with the precarious position of his eminent charge. We should notice that Madame de Maintenon, by securing Godet the vacant See of Chartres, consolidated her influence over the royal foundation: the same man was head of her private conscience and her public project of charity.

22 Cf. Masson M., 'La correspondance spirituelle de Fénelon avec Madame de Maintenon' Revue d'histoire littéraire de la France 13 (1906) 51-72.

23 Letter from Fénelon to Tronson, 6 Novembre 1694, in Fénelon François, Correspondance, ed. Orcibal J., with the collaboration of Le Brun J. - Noye I. - Neveu B., 18 vols. (Paris/ Geneva: 1972-2007) vol. 2 (1972) 301-302, cf. Fénelon, "Explication de quelques 


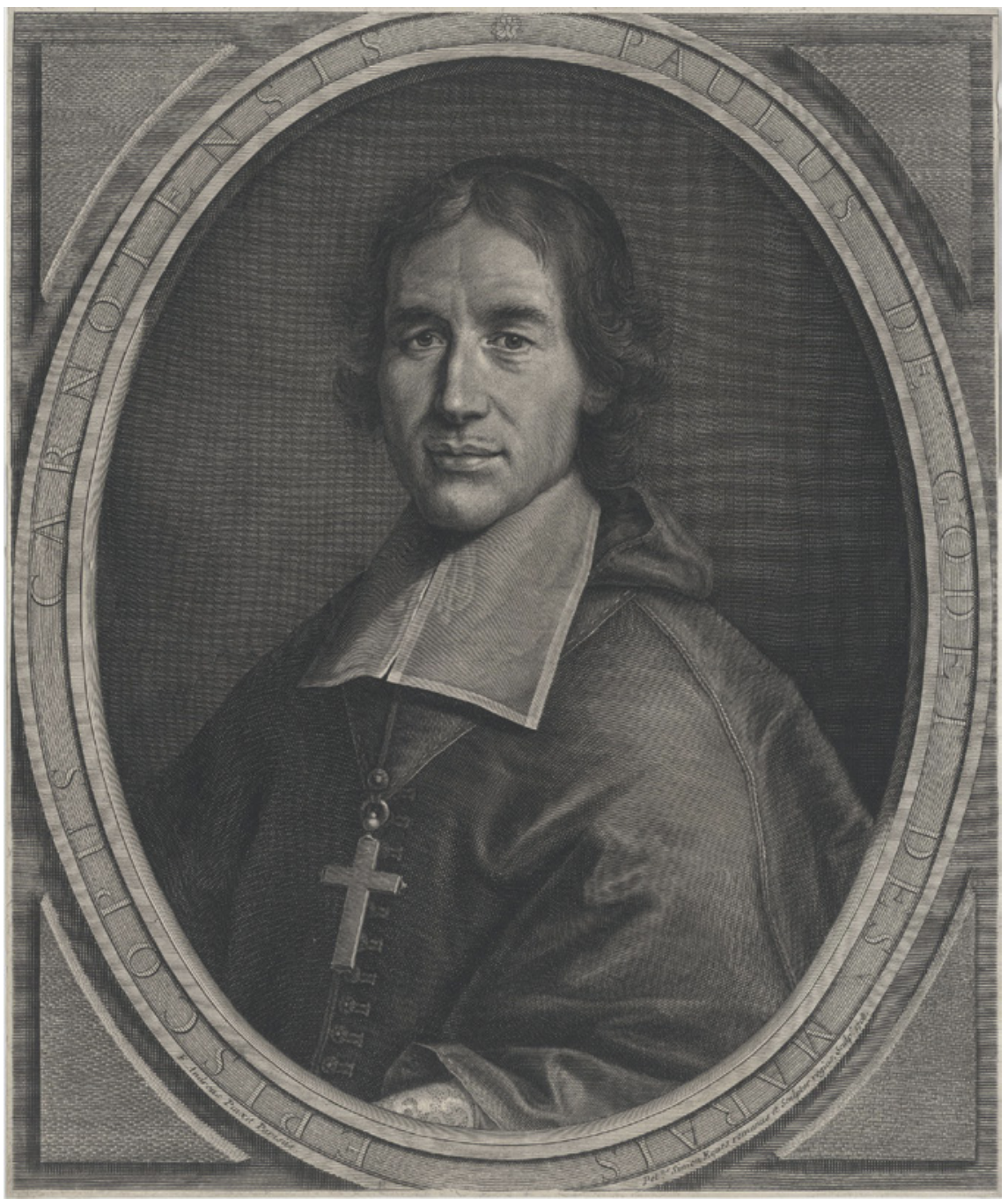

FIGURE 15.5 Pierre Simon (engraver) after François Andriot (designer), portrait of Paul Godet des Marais, bishop of Chartres (1708). Etching and engraving, $46,2 \times 38,4 \mathrm{~cm}$

IMAGE (C) TRUSTEES OF THE BRITISH MUSEUM 
Maintenon. Both as founder of a religious community and as someone with unprecedented access to the king, she would be guilty by mere association to heretical teachings. As the process against Guyon developed, and the bishop of Cambrai continued to voice his claims, we can imagine Maintenon's fears steadily growing stronger. Indeed, Mignard's portrait can be seen as engaging with these fears of heresy.

\section{3}

\section{Miraculous Letters}

By painting the king's secret wife in the guise of a saint, Mignard casts the sitter in an ideal mould and thereby represents her as more than a historical individual; she is seen to embody specific aspects of saintliness. Francesca Bussa dei Ponziani (1384-1440) was a noble roman matrone, known as a charitable wife, miraculous healer, and mystic. As widow she had founded a community of Benedictine oblates in the convent of Tor de' Specchi in Rome. As the first woman canonized since the Reformation (16o8), saint Frances of Rome held a special place in Counter-Reformation hagiography. ${ }^{24}$ Her cult was promoted by saint François de Sales (1567-1622) and saint Jeanne de Chantal (1572-1641), who, in 16o9, founded the Order of the Visitation. Indeed, they saw her as an epitome of female sanctity when creating this charitable order. ${ }^{25}$ When Madame de Maintenon launched her project of reforming Saint-Cyr, she called upon a number of Visitandines, who from 1692 until 1694 assisted in the regulation of its religious praxis.

The principal virtue of saint Frances was a perfect conformity of her will to the will of God. As an example of female piety, she struck the perfect balance between devotion to God and prompt obedience to her husband. According to the saint's Vita, Frances of Rome was married for forty years but without ever having any marital disagreement. ${ }^{26}$ With the consent of her husband, she

expressions tirées des lettres de Fénelon à Madame de Maintenon" [Novembre 1694], in Fénelon, Correspondance vol. 2, 302-312.

24 Barone G., "Francesca Romana santa della Riforma cattolica", in Bartolomei Romagnoli A. - Picasso G. (eds.), La canonizzazione di Santa Francesca Romana. Santità, Cultura e Istituzioni a Roma tra Medioevo ed Età Moderna, La mistica cristiana tra Oriente e Occidente 20 (Florence: 2013) 125-138.

25 See Mezzadri L., "San Francesco di Sales e santa Francesca Romana alle origini della Visitazione", in Bartolomei Romagnoli - Picasso (eds.), La canonizzazione di Santa Francesca Romana $215^{-23}$.

26 Acta Sanctorum, 53 vols. (Antwerp, Jacobus Meursius: 1643-1794) vol. 7, Martii II/III (1668) 88-216. The first vita of the saint was based on notes by her confessor Giovanni Matteotti and Maria Magdalena Anguillaria, prioress of Tor de' Specchi. The Jesuit Virgilio 
practiced continence and spent days in retreat and prayer in her private oratory. The hagiographic accounts also describe how promptly she would lay aside her book of hours and attended to domestic duties, whenever her husband called her away from devotional exercises. On one occasion, as she prepared to recite a particular verse from the Office of Our Lady, he interrupted four times in a row, but on her fifth attempt a miracle occurred: she found, miraculously, that the letters in her book of hours had become gilded. This book is still kept as a relic in the monastery of Tor de' Specchi. ${ }^{27}$

It is hard to determine how well-known this particular episode from the life of the saint was in late seventeenth-century France. Within the hundredthirty pages on the saint in the Acta Sanctorum, it comprises but one short paragraph. ${ }^{28}$ The printed Vita conveys an equally short mention. ${ }^{29}$ In the iconography of saint Frances of Rome, she is often depicted with a book and an angel [Fig. 15.6], yet these attributes have little or no narrative connection to the miracle cited above. ${ }^{30}$ Occasionally, if incidentally, the miracle featured in writing, notably in the works of François de Sales. Thus, it figures prominently in the twelfth book of the Traité sur l'amour de Dieu (1616). ${ }^{31}$ In this final book, the 'I' shares with his interlocutor, Théotime, 'quelques avis pour le progrès de l'âme au saint amour' (certain counsels for the progress of the soul in holy love). ${ }^{32}$ The first piece of advice returns to a central feature of De Sales' theoretical framework:

Cepari (1564-1631) subsequently published it for a wide audience: Cepari Virgilio, Vita di santa Francesca Romana, fondatrice dell'Oblate di Torre de Specchi cavata da vari manoscritti antichi, dalli processi fatti per la sua canonizazione ed alter istorie, data nuovamente in luce dalla Madre Presidente, ed Oblate di Torre de'Specchi (Rome, s.n: 1675).

27 For a contemporary visit to the monastery and mentioning of the precious book turned relic and therefore on display but not to be opened, see De Coulanges Philippe Emmanuel, "Mémoires de M. de Coulanges. Conclaves d'Alexandre VIII et d'Innocent XII" in Mémoires de M. de Coulanges, Suivis de Lettres Inédites de Madame de Sévigné, de son fils, de l'abbé de Coulanges, d'Arnauld d'Andilly, d'Arnauld de Pomponne, de Jean de La Fontaine, et d'autres personnages du même siècle, ed. Monmerqué J.-L.-N. (Paris: 1820) 77-325 (299-300).

28 Acta Sanctorum vol. 7, Martii II/III, 184.

29 Cepari, Vita di santa Francesca Romana 72.

30 See Brizzi G., "Contributo all'iconografia di Francesca Romana," in Picasso G. (ed.), Una Santa tutta Romana. Saggi e ricerche nel VI centenario della nascita di Francesca Bussa dei Ponziani (1384-1984) (Siena: 1984) 265-355. See also Toscano B., "Iconografia e storia dell'arte. Riflessioni su un libro di Giovanni Brizzi”, in Bartolomei Romagnoli A. Picasso G. (eds.), La canonizzazione di Santa Francesca Romana 363-370.

31 De Sales François, "Traité de l'Amour de Dieu", in CEuvres, ed. A. Ravier (Paris: 1969) 333$972(947-972)$.

32 De Sales, "Traité de l'Amour de Dieu" 947. 


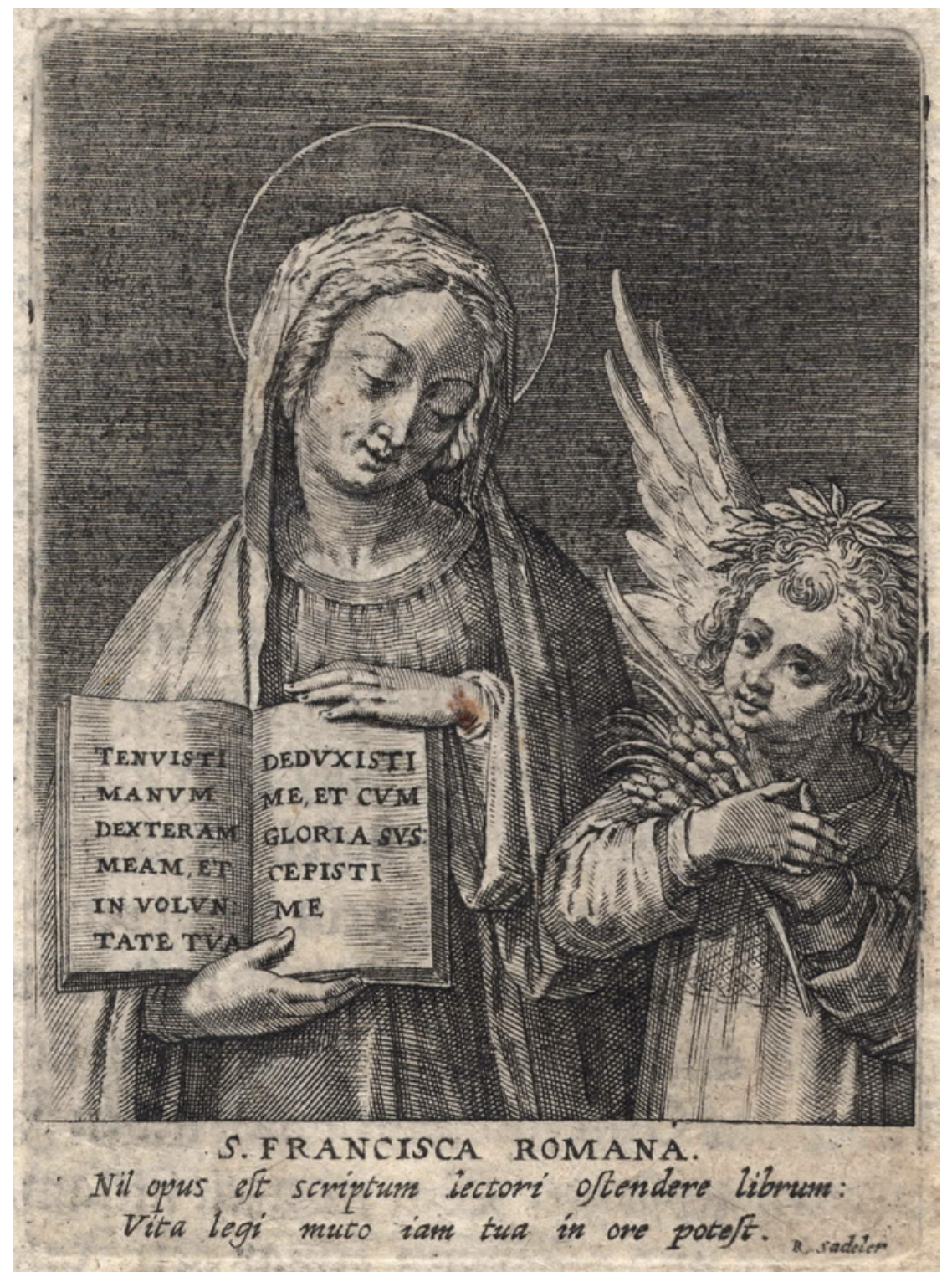

FIGURE 15.6 Raphael Sadeler, St Frances of Rome (1610). Engraving, 7,5 × 5,5 cm.

From Aegidius Albertinus, Himmlisch Frawenzimmer, Darinn das Leben vier-und-fünffzig der allerheiligisten Junckfrawen und Frawen [...], (Munich: Raphael Sadeler, 1621), p. 389

PRIVATE COLLECTION (C) AUTHOR 
Pour moi, je parle en ce Traité, de l'amour surnaturel que Dieu répand en nos cœurs par sa bonté, et duquel la résidence est en la suprême pointe de l'esprit; pointe qui est au-dessus de tout le reste de notre âme, et qui est indépendante de toute complexion naturelle. ${ }^{33}$

For my part, I speak in this treatise of the supernatural love with which God, out of his goodness, transfuses our hearts, and which resides in the highest point of the spirit; a point that lies beyond all the rest of our soul, and which is independent of all natural disposition.

Following Mino Bergamo's analysis, this 'suprême pointe de l'esprit' lies at the heart of the entire work and of the entire Salesian model of the soul. It is a point that is located within the soul, but it points beyond the soul's realm. However, it is not a hidden essence, which reveals itself as the violent intrusion of the divine. Furthermore, it is no stable part of the soul's rational capacities as these are distinguished from its vegetative and sensory capabilities. Instead, De Sales offers a much more fragmented image of the rational soul and its different faculties; these faculties or, better, forces operate complementarily when a person turns towards the divine. ${ }^{34}$ Positing such a structure in the first chapter, book twelve then examines human desire in chapters two and three: in the progress of holy love, the soul should desire, continually, to love God and thereby free itself of worldly passions and desires; the illumination of the soul its supernatural love of God - constitutes a continuous process that requires the abnegation of terrestrial things and 'les niaises, vaines et superflues occupations, desquelles nous nous chargeons, qui nous divertissent de l'amour de Dieu, et non pas les vrais et légitimes exercices de nos vocations' (the silly, vain and superfluous activities whereto we incline: they distract us from the love of God and are not the true and fitting exercises of our vocations). ${ }^{35}$ Indeed, the fourth chapter proceeds to outline how the desire for the divine, seated in the complex workings of the rational faculties of the soul, does not contradict an active engagement with the world. Saint Bernard, for one, continued to progress in holy love, although, as a Cistercian monk, he was dragged back into the world and its affairs, and was compelled to serve great princes; 'il changeait de lieu, mais il ne changeait point de cœur, ni son cœur d'amour, ni son amour d'objet' (he changed location, but his heart did not change, his heart did not change its love, his love did not change its object). Unlike the chameleon, the

33 Ibid. 949 .

34 Bergamo M., L'anatomie de l'âme. De François de Sales à Fénelon (Paris: 1994) 23-136.

35 De Sales, "Traité de l'Amour de Dieu" 954. 
saint's devotional attitude was not coloured by his surroundings: instead, he remained 'toujours tout uni à Dieu, toujours blanc de pureté, toujours vermeil de charité, et toujours plein d'humilité' (always wholly united with God, ever white in purity, bright-red with charity, and ever full of humility). ${ }^{36}$ If corresponding with the necessity of one's duty, engaging with the world 'à la cour, au palais, à la guerre' (at court, in public office, in war) does not contradict the will of God.

The fifth chapter of the twelfth book of De Sales' treatise is simply entitled "Exemple très-amiable sur ce sujet" (A very beautiful example of this topic). It argues that legitimate occupations do not at all preclude the practice and progress of holy love:

Le rossignol n'aime pas moins sa mélodie quand il fait ses pauses, que quand il chante, le cœur dévot n'aime pas moins l'amour quand il se divertit pour les nécessitez extérieures, que quand il prie, leur silence \& leur voix, leur action \& leur contemplation, leur occupation \& leur repos, chantent également en eux le Cantique de leur dilection. ${ }^{37}$

The nightingale loves his melody no less when he makes his pauses than when he sings, [and so] the devout heart does not cherish love less when it is diverted by exterior necessities, than when it prays: their silence and voice, action and contemplation, occupation and repose, equally sing within them the hymn of their love.

It is within this context, where withdrawal from the world and engagement in the world are reciprocated in a measured way, that De Sales evokes saint Frances:

Un jour sainte Françoise, disait l'office de nostre Dame, \& comme il advient ordinairement, que s'il n'y a qu'une affaire en toute la journée, c'est au temps de l'oraison, que la presse en arrive, cette sainte Dame fut appelée de la part de son mary pour un service domestique, \& par quatre diverses fois pensant reprendre le fils de son office, elle fut rappelée \& contrainte de couper un même verset, jusques à ce que cette bénite affaire, pour laquelle on avait si empressement diverti sa prière, étant en fin achevé revenant à son office, elle trouva ce verset si souvent laissé par obéissance, \& si souvent recommencé par dévotion, tout écrit en beaux caractères d'or, que sa dévote compagne Madame Vannocie jura d'avoir

$36 \quad$ Ibid. 955 .

37 Ibid. 956. 
vue écrire, par le cher Ange gardien de la sainte, à laquelle par après sainte Paul aussi le révéla. ${ }^{38}$

One day, saint Frances was reciting the Office of Our Lady, and as often happens, if there is but one item of business during the whole day, it falls during the time of prayer; the message arrived that this lady was being summoned by her husband for some domestic duty, and four different times, thinking [afterward] to continue her office where she had left it, she was called back, forced to interrupt the same verse. The blessed duty, for which she had so willingly deferred her prayer, having finally been achieved, upon returning to her Office, she found that this verse, so often left in obedience, and so often recommenced in devotion, had been wholly written in beautiful letters of gold, which her devote companion Madame Vannozza swore to have seen written by the dear Guardian Angel of the saint, to whom later saint Paul also revealed this.

Clearly, the gilded letters in Mignard's painting are meant to evoke this exact miracle. Hence, the text seems less important than its materiality; the golden letters are key to reading the painting as a 'visual parable'. They draw attention not only to the saint's married state - and by implication to that of Maintenon - but also to her marital commitment as a moral exemplum. The sitter's equivocal station at court is represented as the univocal balance between contemplative withdrawal and charitable engagement: the portrait communicates Maintenon's marital status, but also puts her interior on display; her union with the divine in devotional contemplation does not circumvent the obligations that follow from her position 'auprès du Roi'.

It may be asked with whom the idea to depict Maintenon in this particular fashion could have originated? From the moment Mignard was appointed Peintre $d u$ Roi, Louis XIV was his only patron, and his works were by default royal commissions [Fig. 15.7]. The poem by Catherine Bernard suggests that the painter came up with the invention; and his long roman sojourn may account for a detailed familiarity with saint Frances of Rome and the specifics of her life. ${ }^{39}$

38 De Sales, "Traité de l'Amour de Dieu" 956.

39 Pierre Mignard was known as 'le Romain', because he had spent an extensive period in Rome (1636 to 1657 ) before being called back to France by the king. 


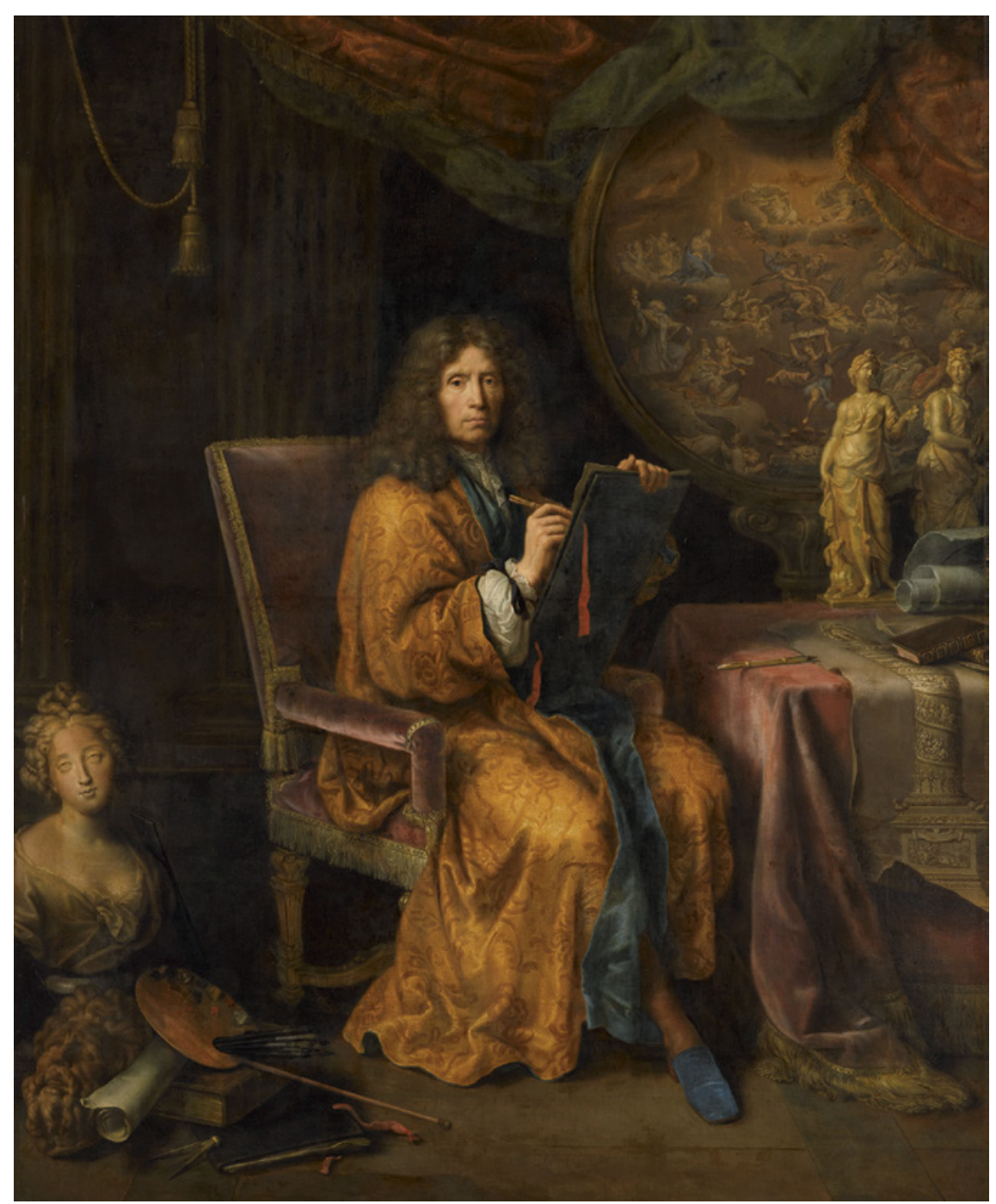

FIGURE 15.7 Pierre Mignard, self-portrait of the painter in his studio (c. 169o). Oil on canvas, $235 \times 188 \mathrm{~cm}$. Paris, Musée du Louvre

PHOTO (C) RMN-GRAND PALAIS / FRANCK RAUX 
Yet given the extent of control exerted by Maintenon e.g. in building matters at Saint-Cyr, we can be certain that she had a say in how she was immortalized. ${ }^{40}$ Indeed, it seems that Maintenon sent various copies of the painting to friends, relatives and her network: for a considerable period of time, the king's secret wife was content with broadcasting this image of herself. Moreover, after her death a copy of the portrait in some form was found in every classroom at Saint-Cyr. ${ }^{41}$ It is important to note that besides referencing a specific hagiographic episode, Mignard's gilded letters also carry meaning on the textual level. Indeed, the hagiography only mentions that words from the Little Office were miraculously transformed, but it makes no mention of the specific words. As a relic, the book of hours remains closed, it is not to be opened, and no story informs us what specific verse had changed nature as a testimony to the saint's obedience. The choice to show this specific antiphon, gilded and conspicuously evoking nuptial imagery, is thus a deliberate act of artistic licence. While Mignard may have brought the Roman saint to Maintenon's attention, some level of agency in the conception of the portrait may also be sought on the part of other actors involved in the shaping of her public and private persona, particularly her spiritual director. In an undated letter, ${ }^{42}$ Godet states:

Le portrait que vous avez eu la bonté de m'envoyer, Madame, par rapport à votre état me paraît bien véritable et m'effrayerait si je ne savais que Dieu vous y a introduit d'une manière qui paraît miraculeuse et si

40 See Manseau Pierre, Taphanel A. (ed.), Mémoires de Manseau, Intendant de la maison royale de Saint-Cyr pub. d'après le manuscrit autographe (Versailles: 1902).

41 As noted by Horace Walpole, who visited the school in 1769. Horace Walpole, Letters of Horace Walpole, ed. Charles Duke Yonge, vol. 2 (New York, 189o) 112-113. This observation is corroborated by, e.g., the inventories made during the French Revolution, cf. Archives Départementales des Yvelines, Mss. D 112-118.

42 Exceeding three hundred in number and spanning twenty years, Godet's letters of spiritual direction survive in copy. The principal compilations date to the first half of the 18th century: Lettres spirituelles de M. l'abbé des Marais, évêque de Chartres, à Mme de Maintenon vol. 1, Médiathèque Michel-Crepeau, La Rochelle (hereafter: BmR), Ms. 1759; Lettres spirituelles de M. l'abbé des Marais, évêque de Chartres, à Mme de Maintenon vol 2, Société Archéologique et historique de l'Orléanais (hereafter: SAHO), Ms. G 14; Les Lettres Edifiantes, Bibliothèque municipale de Versailles (hereafter: BmV) Mss. 63-67. All of these compilations originate from Saint-Cyr. We should also mention that Madame de Maintenon, as part of her devotional praxis, copied Godet's letters into small booklets. Today, nine booklets survive containing an excess of seventy copies of letters from Godet: Les Petits Livres Secrets BmV Mss. P 36-42; P 98; Bibliothèque nationale de France, Ms. Fr. 13249. The relationship between Maintenon's copies, created from 1689 until Godet's death in 1709, and the later compilations of copies poses a number of fascinating questions that we disregard in the following. 
je ne voyais sensiblement qu'il est avec vous, vous soutenant de sa main toute-puissante et vous dirigeant en tout. ${ }^{43}$

The portrait which you have had the kindness to send me, Madame, with regard to your particular condition seems to me very true and would frighten me if I did not know that God introduced it to you in a manner that appears miraculous, and if I did not see appreciably that he is with you, sustaining you with his all-powerful hand and directing you in everything.

This letter, undated but possibly from the 169os, shows Maintenon taking personal pride in, if not ownership of, the iconography, while Godet des Marais hints at a certain unease with the way she is represented. Yet, the bishop and director condones it by reference to the divine and miraculous origin of this method of portrayal.

As mentioned above, the book of hours depicted in the portrait shows the text of an antiphon from the Office of Our Lady. This antiphon combines Canticle 1:3 and Canticle 1:2: 'In odorem unguentorum tuorum currimus: adolescentulae dilexerunt te nimis' (Into the odor of thy ointments we run: young maidens have loved thee exceedingly). Both as signifiers of textual meaning and as a hagiographical prompt, the gilded antiphon is crucial for the interpretation of Mignard's portrait. It should be noted that the interpretation of these lines was highly controversial in late seventeenth-century France, as they were associated with the 'Quietists' and used in the polemic against their 'false' mysticism. ${ }^{44}$ The aforementioned Madame Guyon dwelt on these verses in her controversial commentary on the Canticle of Canticles. In her reading of Canticle 1:3, ${ }^{45}$ Guyon interprets the first sentence as an utterance that the bride addresses to the bridegroom from the centre of her soul: the 'trahe me' (draw me in) is an utterance voiced by the soul in its most intimate recess. In the second part of the verse, the plural ('post te curremus'/ we will run after you) relates to the forces of the bride's soul ('mes puissances') and her senses ('mes sens'). By the more profound union of essences, explicated in the desire to be drawn in, Guyon argues that the cognitive capabilities can also run after the bridegroom. To be drawn ('tirer') is thus equal to an essential union and

43 Lettres spirituelles de M. l'abbé des Marais, évêque de Chartres, à Mme de Maintenon vol. 1, BmR, 454 .

44 Bell D.N., A Saint in the Sun. Praising Saint Bernard in the France of Louis XIV (Collegeville $\mathrm{MN}$ : 2017) 26-5o.

45 Guyon Jeanne-Marie, Le Cantique des Cantiques de Salomon, interpreté selon le sens mistique \& la vraie representation des états interieurs (Lyon, Antoine Briasson: 1688) 12-13. 
circumscribes this state that is accomplished by the forces of the soul and allows it to engage with ('attirer') the divine.

In Godet's episcopal response to Guyon's writings, he accused her of positing that the soul, already in this life, was able to unite itself with God without any external mediation ('immédiatement') or method of procedure ('sans moyen'). ${ }^{46}$ However, Godet des Marais, in his role as spiritual director, often engaged with the same nuptial imagery. In one of his letters, dated to 14 August 1708, ${ }^{47}$ Madame de Maintenon's 'directeur de conscience' thus exhorts her to say the following prayer:

Priez-le [Dieu] donc humblement et avec confiance qu'il nous relève après nous avoir humiliés et qu'il rende la France plus chrétienne que jamais. Dites, Madame, demain à l'époux de votre âme ce que l'épouse par excellence lui dit dans le Cantique des Cantiques: 'tirez-moi après vous, nous courrons après l'odeur de vos parfums', c'est le langage de Marie. ${ }^{48}$

Therefore, pray to him [God] in a humble manner and with the conviction that he, after having humiliated us, will lift us up and make France more Christian than ever before. Madame, say tomorrow to the spouse of your soul that which the ultimate bride says to him in the Canticle of Canticles: 'Draw me after you; we will run after the odour of thy ointments' - this is the language of Mary.

In this letter, the bishop is not merely referring Madame de Maintenon to the words of Canticle 1:3, as they appear on the printed page. Rather, the letter refers these words to the language of Mary - that is, to the Office of Our Lady:

[...] courez, dans cette Sainte Octave, à l'odeur céleste de l'époux, courez après l'épouse et avec la Sainte vierge, la plus excellente de toutes les épouses, faites courir avec vous les âmes faibles qui sont avec vous à

46 Godet des Marais Paul, Ordonnance et instruction pastorale de Monseigneur L'Evêque de Chartres pour la condamnation des Livres intitulés Analysis orationis mentalis \&c. Moien court \& très-facile de faire oraison \&c. Règle des Associes à l'Enfance de Jésus \& c. Le Cantique des Cantiques de Salomon, interprété selon le sens mistique \&c. \& d'un Manuscrit qui a pour titre Les Torrens (Paris, Louis Josse: 1695) 37. The text was signed at Saint-Cyr on Monday 28 November 1695, while the royal privilege dates to 24 November 1695 .

47 Letter from Godet des Marais to Madame de Maintenon, 14 August 1708; BmV Ms. P 40, f. 5 o- $59 \mathrm{v}$.

48 Letter from Godet des Marais to Madame de Maintenon, 14 August 1708; BmV Ms. P 40, f. 5 ov -51 . 
Saint-Cyr et pour faire courir ces jeunes filles que vous avez gagnées aux divin époux. 49

[...] on this holy Sunday, run toward the odour of the heavenly bridegroom, run after the bride and alongside the Holy Virgin, that most excellent of all brides; cause the weak souls who are with you at Saint-Cyr, to race alongside you, making these young girls run, whom you have won for the divine bridegroom.

Simultaneously, Madame de Maintenon is to run ('courir') and to make run ('faire courir'). Her relation to the divine is an interior state, and in her prayers she is to address the bridegroom of her soul, thereby running in the footsteps of Mary. However, this interior experience does not stand alone: it is circumscribed by a commitment to make the 'demoiselles' at Saint-Cyr run after their 'foundatrice'. As the king's wife follows the model of the Virgin, the young virgins are to follow her. Returning to Mignard's portrait, the 'adolescentulae' (Canticle 1:2) thus translate to the 'demoiselles', educated at Saint-Cyr and thus running after Maintenon: the portrait communicates how these girls have loved the king's wife and followed her example; to its courtly and cloistered viewers, the painting communicates a charitable engagement.

Focusing on the painted letters, Godet's spiritual letter also integrates various excerpts from saint Bernard's Sermones in Cantica Canticorum. In the letter quoted above, the bishop engages with $\S 4$, 5 , $§ 10$ and $\S 12$ from "Sermo XXI".50 First, Godet samples $\S 4$ and makes an incremental change to its wording. In the saint's exegesis, the act of being drawn is interpreted as something needed 'quoniam refriguit paulisper in nobis ignis amoris tui' (because 'the fire of your love has somewhat cooled in us). This makes it impossible for 'us' to run after the bridegroom in the same way as 'we' did just recently. Finally, 'curremus autem postea, cum reddideris laetitiam salutaris tui, cum redierit melior temperies gratiae, cum Sol iustitiae iterum incaluerit' (we will be able to run, when you will have restored the joy of your salvation, when the warmth of grace will have returned, when the Sun of Righteousness, again,

49 Letter from Godet des Marais to Madame de Maintenon, 14 August 1708; BmV Ms. P 40, f. 59-59v.

50 Bernard of Clairvaux, "Sermo XXI", in Sancti Bernardi abbatis primi Claravallensis. Genuina sancti doctoris Opera quatuor prioribus tomis complectens. Post Horstium denuo recognita, aucta, \& in meliorem digesta ordinem, necnon novis prcefationibus, admonitionibus, notis \& observationibus, indicibusque copiosissimis locupletata \& illustrata, secundis curis domni Johannis Mabillon, presbyteri \& monachi benedictini è congregatione S. Mauri, ed. Mabillon J., 2 vols. (Paris, Jean-Baptiste Coignard: 169o) vol. 1, 1330-1334. 
will have grown warm).${ }^{51}$ Godet cites these words in translation, ${ }^{52}$ but displaces saint Bernard's addressee from the first-person plural ('in nobis', 'nec valemus', 'curremus') to the first-person singular ('en moi', 'cette froideur m'empêche de courir comme je faisais hier et ces jours passés', 'Mais je courrai [...] lorsque le soleil de justice répandra sa chaleur sur moi'). These incremental displacements centre saint Bernard's words on Madame de Maintenon and her interior state of distress. This strategy of presentation continues as the spiritual letter jumps to the following passage: '[...] curremus, quoniam abscedet torpor qui nunc est, et revertetur devotio' (We will run, because the present indolence will recede, and devotion shall return). ${ }^{53}$ Again, the bishop's translation focuses the words on Maintenon by changing the grammatical number: '[...] parce que l'engourdissement où je suis maintenant se retirera de moi, la dévotion reprendra sa place, tellement je courrai alors sans peine' (because the lethargy, in which I am now, will withdraw from me, devotion will reclaim its place, and thus I will run without troubles) ${ }^{54}$ The spiritual letter thus changes past words and makes them speak, directly, to the state of its specific addressee: the wish to be drawn towards Christ as bridegroom is inscribed into a spiritual predicament; past words portray present predicaments..$^{55}$

\section{5}

\section{Imitation}

We should here return to the verses from the Canticle, whose sequence is conflated because their material support in Mignard's painting is no Bible but rather a book of hours. Restoring the first verse to its biblical original (Canticle 1:3), we read: 'Trahe me, post te curremus in odorem unguentorum tuorum' (Draw

\footnotetext{
$51 \quad$ Bernard of Clairvaux, "Sermo XXI" 1331.

52 The bishop is not simply quoting a translation but actively engaging with the saint's formulations. His French version, however, seems close to: Bernard of Clairvaux, "Sermo XXI" in Bernard of Clairvaux, Les Sermons de Saint Bernard sur le Cantique des cantiques. Nouvelle édition revue \& corrigée en François, trans. Pierre Lombert (Paris, A. Dezallier/ Lyon, L. Plaignard: 1686 [1663]) 218-232.

53 Letter from Godet des Marais to Madame de Maintenon, 14 August 1708; BmV Ms. P 40, f. $5^{1-51 v}$.

54 Bernard of Clairvaux, "Sermo XXI" 1331.

55 Within this space of interpretation, we might also recall the Sun of Righteousness (Malachi 4:2), whose return saint Bernard anticipates: the present impasse shall be overcome, when the joyous light of salvation shines forth and melts the icy hearts; this divine act is the act of drawing in, which will again enable the brides to run after their bridegroom. In the portrait, the light breaking through in the upper left corner of an interior setting - quite unusual in portraits by Mignard- might be an allusion to this.
} 
me in: we will run after you into the odour of Your ointments). This utterance is ascribed to 'Chorus Adolescentularum' (the choir of the young maidens), who collectively address 'sponsa' (the bride). However, saint Bernard notes an apparent inconsistency: why 'draw me' and not 'draw us', which would match the grammatical number of 'curremus' (we will run)? Resolving this tension, Bernard begins by posing the following question:

Quid enim? fortene sponsa indiget trahi, et adolescentulae non indigent? O pulchra, o felix, o beata! edissere nobis huius distinctionis rationem. Trahe me, ais. Quare, me; et non, Nos? An hoc bonum invides nobis? Absit.

What does this mean? Could it be that the bride has need of being drawn in, whereas the young maidens have no such need? O beautiful, $\mathrm{O}$ happy, $\mathrm{O}$ blessed, explain to us the meaning behind this distinction. Draw me, you say. Why 'me', and not rather 'us'. Do you envy us this favor? Surely not. ${ }^{56}$

In the letter of August 1708, Godet des Marais refers to this exegetical problem, ${ }^{57}$ which is also developed at length in an earlier letter, ${ }^{58}$ wherein he engages with saint Bernard's "Sermo XXI". ${ }^{59}$ Here, the bishop is not addressing a state of distress but rather 'un nouveau désir d'avancer dans les vertus de votre état et un nouvel amour pour notre Seigneur Jésus-Christ' (a new desire to advance in the virtues of your state and a new love for our Lord, Jesus Christ). ${ }^{60}$ The newfound fascination is a means 'pour vous faire courir' (to make you run [after him]). ${ }^{61}$ This is an important point, because the desire to be like Christ is to imitate him - that is, to desire to become the living image of him, who, himself, is 'the image of the invisible God' (Colossians 1:15). ${ }^{62}$ According to Godet, Christ as the imago Dei entails that everything in the invisible, heavenly realm and everything in the visible, earthly realm have been created by Christ and for Christ (cf. Colossians 1:16-17). The blood that he poured out on the cross has

56 Bernard of Clairvaux, "Sermo XXI" 1333.

57 Letter from Godet des Marais to Madame de Maintenon, 14 August 1708; BmV Ms. P 40, f. 5 iv.

$5^{8}$ Letter from Godet des Marais to Madame de Maintenon, 2 May 1707; SAHo Ms. G 14, 317-352.

59 Letter from Godet des Marais to Madame de Maintenon, 2 May 1707; SAHO Ms. G 14, 319.

6o Letter from Godet des Marais to Madame de Maintenon, 2 May 1707; SAHo Ms. G 14, 317.

61 Letter from Godet des Marais to Madame de Maintenon, 2 May 1707; SAHO Ms. G 14, 318.

62 Cf. Letter from Godet des Marais to Madame de Maintenon, 2 May 1707; sAнo Ms. G 14, 321. 
therefore reconciled everything in heaven and on earth; by his bodily death, Madame de Maintenon has become holy, without fault and irreprehensible as long as she remains firm in the faith and the hope of the Gospel. ${ }^{63}$ Moreover, the glorious descent of Christ, the mystery of his Incarnation, is described as an excess of charity (cf. Ephesians 2:4), which, as foretold and promised by the prophets, converts humankind into the children of God and the future inheritors of divine glory. After the Resurrection, the human condition radically changed: it can now be seen by the light of what is to come; this is the divine wisdom of things.

With explicit reference to Philippians $3: 7-14,{ }^{64}$ Godet engages with 'cette haute connaissance de Jésus-Christ' (this supreme knowledge of Jesus Christ) that saint Paul localizes in the Passion and Resurrection, and which makes individuals conform to Christ's suffering and death and thereby attain their own future resurrection (cf. Philippians 3:10-11). Importantly, Paul explicitly states that he has not yet obtained such a knowledge but is in pursuit of it: the Apostle has not already reached the goal but is pressing towards his prize in Christ, towards whom God calls him from above (cf. Philippians 3:14). ${ }^{65}$

Within the context of a spiritual letter wherein the director addresses Madame de Maintenon's newfound desire to follow Christ, this displacement is important: Godet exhorts Maintenon to be of the same opinion as Paul by often meditating upon these sacred words. The distinction between 'courir' (to run) and 'faire courir' (to make to run) again applies, but in a slightly different manner: the love of Christ and the desire to follow him cannot be fixed on a stable image; it rather sets in motion a process of imitation. This same point is further elaborated by reference to Ephesians 3, according to which the vocation of all the saints on earth is to understand the breadth, length, height and depth of 'ce mystère' - that is, the love Christ has for us, a love surpassing all human knowledge (Ephesians 3:18-19). ${ }^{66}$ In turn, the mystery of the love of Christ - a divine excess of charity towards the whole of Creation - is connected to 2 Corinthians 3, where the Apostle speaks about Moses as having put a veil upon his face and thereby preventing a certain kind of vision (2 Corinthians 3:13). Whereas Moses was veiled, the followers of Christ all behold the glory of the Lord with open face (2 Corinthians 3:18), and if the Gospel that they share remains hidden and unclear, if its message has not yet been

63 Letter from Godet des Marais to Madame de Maintenon, 2 May 1707; SAHO Ms. G 14, $322-323$.

64 Letter from Godet des Marais to Madame de Maintenon, 2 May 1707; SAHo Ms. G 14, 327-329.

65 Letter from Godet des Marais to Madame de Maintenon, 2 May 1707; SAHO Ms. G 14, 329.

66 Letter from Godet des Marais to Madame de Maintenon, 2 May 1707; SAHO Ms. G 14, 331. 
unveiled, this is because its listeners have not yet been illuminated by the light of the Gospel and by the glory of Jesus Christ, who is the living image of God (2 Corinthians 4:3-4). More specifically, the world has still to be transformed into the likeness of this same image, whereby humanity, illuminated by the Spirit of the Lord, advances from clarity to clarity (cf. 2 Corinthians 3:18). ${ }^{67}$

In the perspective of such imaginary transformation, Godet praises Madame de Maintenon on account of her 'yeux du cœur' (eyes of the heart). These eyes have been illuminated by the Spirit of God, and 'le dieu du monde' (the god of the world) has not blinded her, making her unable to see 'cette sublime splendeur de l'Évangile' (the sublime splendour of the Gospel). She is therefore different from the 'chrétiens grossiers' (crude Christians), whose eyes have been blinded by 'la fausse gloire du siècle' (the false glory of the world), and to whom holiness and virtues therefore remain hidden truths. Such 'gens du siècle' are accustomed to praise only what speaks directly to 'leur sensualité, leur orgueil, leur avarice et leur vaine curiosité' (their senses, their pride, their greed and their vain curiosity). ${ }^{68}$

Outlining these different modes of seeing, Godet's letter supports a contemplation of the glory of the Gospel in 'sa bassesse apparente' (its apparent baseness). ${ }^{69}$ The bishop also states that God wants certain souls as his brides, and with these souls He entertains a special kind of relationship: as brides of Christ, souls enter into a special kind of community with the divine; this exclusive relationship, however, does not deprive them of an obligation towards the world. The brides are not alone but rather destined for others. ${ }^{70}$ Mystical in nature, the intimate relationship to the divine thus entails no complete withdrawal from the world: the brides 'qui sont fécondes pour leur époux' (that are fertile towards their bridegroom) cannot remain 'seules' (alone), because their salvation hinges upon an engagement in the world. ${ }^{71}$ As such a bride of Christ, Madame de Maintenon 'ne va pas seule à son époux, elle voudrait lui procurer une gloire abondante, elle court à l'odeur de ses parfums et elle en fait courir beaucoup d'autres après elle' (does not go alone to her bridegroom; he wants to obtain for him an abundance of glory; she runs into the odour of his ointments, and she makes many others run after her). ${ }^{72}$ The difference between singular

67 Letter from Godet des Marais to Madame de Maintenon, 2 May 1707; SAHO Ms. G 14, 332-333.

68 Letter from Godet des Marais to Madame de Maintenon, 2 May 1707; SAHO Ms. G 14, 334.

69 Letter from Godet des Marais to Madame de Maintenon, 2 May 1707; SAHO Ms. G 14, 337.

70 Letter from Godet des Marais to Madame de Maintenon, 2 May 1707; SAHO Ms. G 14, 318.

71 Letter from Godet des Marais to Madame de Maintenon, 2 May 1707; SAHO Ms. G 14, 319.

72 Letter from Godet des Marais to Madame de Maintenon, 2 May 1707; SAHo Ms. G 14, 319. 
and plural - between 'Trahe me' and 'Trahe nos' - can thus be explained as the difference between following a model and being a model. First, Maintenon is to imitate Christ by taking the Virgin as her model: this modelling unfolds in her intimate space and is, as such, a private affair. This intimacy is circumscribed, however, by the fact that Maintenon herself serves as a model: from otherworldliness (following a divine model) springs the desire to reform the world (being a model of the divine). In the singular, a desire to be drawn toward Christ is always already a desire to draw others in and to have them, in the plural, run after you, following you as their model.

According to the spiritual director, this is the 'état' (state) in which Madame de Maintenon finds herself, and accordingly, she is every day to ruminate on the words: 'Draw me after you, we will run'. ${ }^{73}$ In her prayers, she is to give voice, from the bottom of her heart, to the desire to be drawn closer to her divine bridegroom. Following Ephesians 3:20, this interior mode of speaking is stronger than anything the self could piece together in elegant words or imagine with its mental powers. In response, Madame de Maintenon will receive an increasing amount of grace that will allow her 'de courir et d'en faire courir beaucoup d'autres avec vous' (to run and, thereby, make many others run after her).

This description is also designed to help the king's wife approach him that 'vous aimez et pour lequel Dieu vous a mise où vous êtes' (you love and for whom God has placed you where you are). The terrestrial mode of seeing is here linked to the king, who 'a les yeux encore faibles, son cœur néanmoins est religieux et il veut se sauver' (has eyes still weak, although his heart is religious and he wants to save himself). Godet invites Madame de Maintenon, together with Louis XIV, contemplatively to consider:

[...] cette sublimité d'un Dieu anéanti et souffrant expirer sur la croix pour nous rendre saints et pour nous faire un peuple agréable à son père; je sais de vous qu'il est choqué d'entendre lire dans l'Évangile que Jésus-Christ parle toujours le langage des pauvres, mais il faut aider à son infirmité ; montrez-lui la hauteur des mystères de Jésus-Christ dans ce qui paraît bas et faible aux yeux des gens, car ce qui paraît une folie en lui est sagesse de Dieu, et ce qui semble une faiblesse en lui est la force du salut, de la sainteté et de la gloire éternelle des chrétiens.

[...] this sublimity of an annihilated and suffering God, who expires on the cross in order to make us holy and create a people agreeable to 
their Father. From you I have learnt that he is shocked, when hearing the Gospel read, that Jesus always speaks the language of the poor, but it is necessary to relieve his weakness; in what appears base and weak in the eyes of men, show him the summit of the mysteries of Jesus Christ, because what in Him appears a foolishness is the wisdom of God, and what in Him seems a weakness is the force of Salvation, of saintliness and of the eternal glory of Christians.

If Maintenon's ultimate goal was to save the king's soul, and to make France more Christian than ever, she must thus fashion herself into a saintly model.

At first sight, Mignard's painting presents itself as an open book. We may, however, read something between the lines. Depending on the viewer, the painting could disclose a secret - Maintenon's marriage to the king - or constitute a mystery. It dissimulates, concealing and revealing different intentions to viewers with different 'patterns of attention'. By casting Maintenon in the historical attire of a saint, Mignard bypasses issues of decorum that would have arisen due to the sitter's equivocal station. Yet, he consciously puts the viewer on the wrong track by playing with the way we are conditioned to look at portraiture: that is, in a psychological way and by recourse to socio-political rather than religious conventions.

Mignard portrays Madame de Maintenon as the founder of a religious congregation that, like the Visitandines of François de Sales and the Oblates of Francesca Romana, was actively engaged in the world. The gilded letters from Canticle 1:2-3 refer to the royal foundation of Saint-Cyr and its 'adolescentulae'. To those who were familiar with the life of saint Frances of Rome, such as (one may surmise) the members of Maintenon's devout network and the Dames de Saint Louis, the gilded verse also evoked the moral lesson that God prefers prompt obedience to worldly duties over any complete abandonment to a life of devotion. Such duties, when they are exercised in accordance with one's social position, do not contradict God's will: neglect of worldly obligations is rather a dangerous attitude, at best prideful and potentially heretical. The liturgical text of the Little Office / Canticle of Canticles, with its controversial overtones, is thus 'reframed' in an entirely orthodox way: the divine miracle is bestowed upon a Roman Catholic saint precisely because she did not lose herself in devotion, but stayed firmly grounded in the world and its marital 
obligations. The controversy around Quietism would only break out in its full intensity sometime after the portrait was made. Nevertheless, we believe that it must be seen as a (preemptive) response to the potential scandal of quietist tendencies being fostered at the royal foundation. This urgency helps to explain why Maintenon is presented in this particular way, and why the portrait was so actively disseminated: it cleverly modulated the perception of Maintenon at a time when her proximity to the king was potentially compromised.

Viewed in conjunction with the spiritual letters of the bishop of Chartres, Mignard's portrait sheds light on how Maintenon's position and her agency in the world was understood. By playing with the conventional ways of viewing portraits historiés, Mignard challenged the beholder to look beyond superficial appearances and worldly status, and instead to apply (gendered) religious knowledge in recognizing that the portrait (obliquely) addressed the status of Madame de Maintenon as secret royal consort. It thus offered the viewer a visual parable that could only be understood fully by those with the faculty of spiritual discernment. Those who grasped this meaning were also made aware of her humble and obedient attitude towards religion, marriage and politics, and that she did not pose a threat to the Crown.

Pierre Mignard was praised for having singlehandedly elevated the status of portrait painting to the level of history painting. It may very well be his wit or 'esprit', reflecting that of the soul of the sitter, which Monville praised as 'sublime', and which led Catherine Bernard to exclaim: 'Ah, Mignard, que vous louez bien!'

\section{Bibliography}

Acta Sanctorum, 53 vols. (Antwerp, Jacobus Meursius: 1643-1794).

Bajou T., "À propos de quelques tableaux de Mignard à Versailles", in Boyer J.-C. (ed), Pierre Mignard "le Romain" (Paris: 1997) 195-224.

Bajou T., Les Peintures à Versailles : XVIIe Siècle (Paris : 1998).

Barbafieri C., "Le théâtre de Catherine Bernard, ou comment être moderne dans le genre tragique à la fin du XVIIe siècle", in Bahier-Porte C. - Poulouin C. (eds.), Écrire et penser en Moderne (1687-1750) (Paris: 2015) 321-336.

Barone G., "Francesca Romana santa della Riforma cattolica", in Romagnoli B.A. Picasso G. (eds.), La canonizzazione di Santa Francesca Romana. Santità, Cultura e Istituzioni a Roma tra Medioevo ed Età Moderna, La Mistica cristiana tra Oriente e Occidente 20 (Florence: 2013) 125-138. 
Bell D.N., A Saint in the Sun. Praising Saint Bernard in the France of Louis XIV (Collegeville MN: 2017).

Bergamo M., L'anatomie de l'âme. De François de Sales à Fénelon (Paris: 1994).

Bernard of Clairvaux, "Sermo XXI", in Sancti Bernardi abbatis primi Claravallensis. Genuina sancti doctoris Opera quatuor prioribus tomis complectens. Post Horstium denuo recognita, aucta, \& in meliorem digesta ordinem, necnon novis prefationibus, admonitionibus, notis \& observationibus, indicibusque copiosissimis locupletata \& illustrata, secundis curis domni Johannis Mabillon, presbyteri \& monachi benedictini è congregatione S. Mauri, ed. Mabillon J., 2 vols. (Paris, Jean-Baptiste Coignard: 169o). Bernard Catherine, Piva F. (ed.), Oeuvres complètes, 2 vols. (Paris - Fasano: 1999).

Bernard of Clairvaux, Les Sermons de Saint Bernard sur le Cantique des cantiques. Nouvelle édition revue \& corrigée en François, trans. Pierre Lombert (Paris, A. Dezallier - Lyon, L. Plaignard: 1686).

Brizzi G., "Contributo all'iconografia di Francesca Romana”, in Picasso G. (ed.), Una Santa tutta Romana. Saggi e ricerche nel VI centenario della nascita di Francesca Bussa dei Ponziani (1384-1984) (Siena: 1984) 265-355.

Bruun M.B - Havsteen S.R. - Mejrup K. - Nagelsmit E. - Nørgaard L.C., "Withdrawal and Engagement in the Long Seventeenth Century: Four Case Studies", Journal of Early Modern Christianity 1 (2015) 249-343.

Cepari Virgilio, Vita di santa Francesca Romana, fondatrice dell'Oblate di Torre de Specchi cavata da vari manoscritti antichi, dalli processifatti per la sua canonizazione ed alter istorie, data nuovamente in luce dalla Madre Presidente, ed Oblate di Torre de'Specchi (Rome, s.n: 1675).

Coquery E. (ed.), Visages du Grand Siècle: Le portrait français sous le règne de Louis XIV, 166o-1715, exh. cat. Musée des Beaux-Arts, Nantes - Musée des Augustins, Toulouse (Paris: 1997).

De Boislisle A., Paul Scarron et Françoise d'Aubigné. D'après des documents nouveaux (Paris: 1894).

De Coulanges Philippe Emmanuel, "Mémoires de M. de Coulanges. Conclaves d'Alexandre VIII et d'Innocent XII" in Mémoires de M. de Coulanges, Suivis de Lettres Inédites de Madame de Sévigné, de son fils, de l'abbé de Coulanges, d'Arnauld d'Andilly, d'Arnauld de Pomponne, de Jean de La Fontaine, et d'autres personnages du même siècle, ed. Monmerqué J.-L.-N. (Paris: 1820) 77-325.

De Lastic G., "Contribution à l'oeuvre de Pierre Mignard, portraitiste", Bulletin de la Société de l'Histoire de l'Art français (1980) 167-176.

De Sales François, “Traité de l'Amour de Dieu”, in CEuvres, ed. Ravier A. (Paris: 1969).

Fénelon François, Correspondance, ed. Orcibal J., with the collaboration of Le Brun J. - Noye I. - Neveu B., 18 vols. (Paris/Geneva: 1972-2007). 
Fumaroli M., De Rome à Paris: peinture et pouvoirs aux XVIIe et XVIIIe siècles (Dijon: 2007).

Godet des Marais Paul, Ordonnance et instruction pastorale de Monseigneur L'Evêque de Chartres pour la condamnation des Livres intitules Analysis orationis mentalis \&c. Moien court \& très-facile de faire oraison \&c. Règle des Associes à l'Enfance de Jésus \&c. Le Cantique des Cantiques de Salomon, interprété selon le sens mistique \&c. \& d'un Manuscrit qui a pour titre Les Torrens (Paris, Louis Josse: 1695).

Guyon Jeanne-Marie, La Vie par elle-même et autres écrits par elle-même, ed. Dominique Tronc, 2 vols, (Paris: 2014).

Guyon Jeanne-Marie, Le Cantique des Cantiques de Salomon, interpreté selon le sens mistique \& la vraie representation des états interieurs (Lyon, Antoine Briasson: 1688).

Le Brun J., La spiritualité de Bossuet (Paris: 1972).

Ledieu François, "Mémoires de l'abbé Ledieu sur le quiétisme” [1699], ed. Levesque E., Revue Bossuet 7 (1907) 19-56.

Manseau Pierre, Taphanel A. (ed.), Mémoires de Manseau, Intendant de la maison royale de Saint-Cyr pub. d'après le manuscrit autographe (Versailles: 1902).

Masson M., "La correspondance spirituelle de Fénelon avec Madame de Maintenon", Revue d'histoire littéraire de la France 13 (1906) 51-72.

Mazière de Monville Simon-Philippe, La Vie de Pierre Mignard, premier peintre du roy, par l'abbé de Monville, avec le poème de Molière sur les peintures du Val-de-Grâce et deux dialogues de M. de Fénelon, Archevêque de Cambray, sur la peinture (Paris, Jean Boudot - Jacques Guérin: 1730).

Mezzadri L., "San Francesco di Sales e santa Francesca Romana alle origini della Visitazione", in Bartolomei Romagnoli A. - Picasso G. (eds.), La canonizzazione di Santa Francesca Romana. Santità, Cultura e Istituzioni a Roma tra Medioevo ed Età Moderna, La mistica cristiana tra Oriente e Occidente 20 (Florence: 2013) 215-230.

Nikolenko L., Pierre Mignard: Portrait Painter of the Grand Siècle (Munich: 1983).

Nørgaard L.C., Sources of Spiritual direction (Ph.D. dissertation, University of Copenhagen: 2017).

Phélypeaux Jean, Relation de l'origine du progrès et de la condamnation du quiétisme répandu en France, 2 vols. (s.l, s.n: 1732).

Schneider M., Bildnis - Maske - Galanterie: das "portrait historie”" zwischen Grand Siècle und Zeitalter der Aufklärung (Berlin - Munich, 2019).

Sévigné Marie de Rabutin-Chantal, Lettres de Madame de Sévigné, de sa famille et ses amis, ed. Monmerqué L.-J.-N., 14 vols. (Paris: 1862-1868).

Shapiro N., French Women Poets of Nine Centuries: The Distaff and the Pen (Baltimore MD: 2008). 
Toscano B., "Iconografia e storia dell'arte. Riflessioni su un libro di Giovanni Brizzi", in Romagnoli - Picasso (eds.), La canonizzazione di Santa Francesca Romana. Santità, Cultura e Istituzioni a Roma tra Medioevo ed Età Moderna, La mistica cristiana tra Oriente e Occidente 20 (Florence: 2013) 363-37o.

Vinha M. da - Maral A. (eds.), Madame de Maintenon. Dans les allées du pouvoir, exh. cat., Château de Versailles (Versailles: 2019).

Walpole Horace, Letters of Horace Walpole, ed. Charles Duke Yonge, vol. 2 (New York, 189o). 